\title{
単一パルス高パワー密度電子ビーム による金属の穴あけ加エ*
}

\author{
宮 崎 俊 行** \\ High Power Density Electron Beam Drilling of Metals by One Pulse \\ Toshiyuki MrYazaki
}

It has been said that the high power density electron beam drilling is performed by the heating inside the target which is caused by the phenomenon that the high potential electrons penetrate into target. However, from the view-points of heat conduction theory and dynamic theory it has not been made clear. In this paper, the mechanism of high power density electron beam drilling of metals is discussed on the bases of heat conduction and force balance between vapour pressure and shrinking pressure due to surface tension. Namely, the critical temperature of generation of molten metal removal and the drilling speed are estimated. The estimated speed coincides with the experimental value. Moreover, the phenomenon of saturation of drilled depth is explained rationally.

\section{1. 緒言}

高パワー密度電子ビームによる金属の穴あけは, 高エ ネルギ電子が試料内部に侵入乙て，試料内部に高温，高 蒸気圧を発生し，溶融部を瞬間的に除去して行う1) 3). しかしながら，その熱伝導論的な解析および溶融体除去 に関する解析は行われていない.

本論文は，電子の試料内部への侵入を考慮した試料の 温度分布から溶融体除去機構を解析し，その臨界条件を 求め, かつビーム照射時間 (パルス幅) を広範囲に変化 させたときの穴深さの変化および穴ふさがり現象につい て実験的解析を行ったものである.すなわち, 本論文は, 前報4で報告した電子の侵入により深い溶融部が形成さ れる以前の現象に関するものである.

\section{2. 電子の侵入を考慮した除去機構の解析}

\section{1 試料の温度分布}

電子ビームの固体中への侵入状況およびエネルギ損失 に関しては，モンテカルロ法による追跡 ${ }^{5)}$ や理論的な計 算(例(6) があり，固体表層下のエネルギ損失割合 $\mathrm{d} E_{A} / \mathrm{d} x$ は次式で与えられている6).

$$
\begin{aligned}
\rho R_{p} \frac{\mathrm{d}\left(E_{A} / E_{0}\right)}{\mathrm{d}(\rho x)}=\frac{1}{(1-y)^{2 / 5}} \exp \left(-\frac{\gamma y}{1-y}\right) \cdot\left(\frac{\gamma}{1-y}+\frac{3}{5}\right) \\
+\frac{E_{B}}{E_{0}} \frac{6 \times 1.9}{5} \frac{\gamma}{(1-y)^{2}} \exp \left(-\frac{1.9 \gamma y}{1-y}\right) \cdot\left(\frac{1}{2^{5 / 6}}-(1-y)^{5 / 6}\right)
\end{aligned}
$$

* 原稿受付 昭和 48 年 12 月 26 日. 昭和 48 年度精機学会 秋季大会学術講演会 (昭和 48 年 10 月 7 日) にて発表.

** 正 会 員 理化学研究所 (和光市広沢 2 番 1 号)

$$
\begin{aligned}
& \rho R_{p}=\frac{2.76 \times 10^{-11} M E_{0}{ }^{5 / 3}}{Z^{8 / 9}} \frac{\left(1+0.978 \times 10^{-6} E_{0}\right)^{5 / 3}}{\left(1+1.957 \times 10^{-6} E_{0}\right)^{4 / 3}} \\
& y=\frac{x}{R_{p}}, \quad \gamma=0.187 Z^{2 / 3}
\end{aligned}
$$

ただし， $E_{A}$ : 電子が表面から深さ $x$ までに失うエネル ギ， $E_{0}$ : 入射電子エネルギ, $\rho$ : 固体の密度, $Z$ : 固体の 原子番号， $M$ : 固体の原子量, $E_{B} / E_{0}$ : 固体材料による 定数, $R_{p}$ : 電子の飛程 (maximum range) である.

一方, 半無限体表面に円形熱源 (半径 $a$, 単位汗一) があるときの熱源中心の表面下の温度上昇 $T^{\prime}(z, t)$ は, 式 (2)で与えられる7).

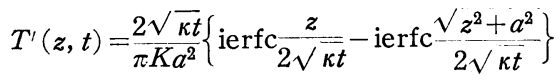

ただし， $K$ : 熱伝導率， $\kappa$ : 温度拡散率,

$$
\operatorname{ierfc}(x)=\frac{1}{\sqrt{\pi}} \mathrm{e}^{-x^{2}}-\frac{2}{\sqrt{\pi}} x \int_{x}^{\infty} \mathrm{e}^{-\xi^{2}} \mathrm{~d} \xi
$$

である・

式 (1),(2)より, 電子の侵入を考慮した試料の温度分布 $T(z, t)$ は, 式(3)で計算できる.

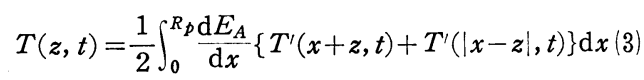

式 (3) を用い，軟鋼 (S 15 C) を後に示す実験条件で加 熱したときの温度分布の計算例が図 1 である. 眓から明 らかなように, 試料表面よりも内部に最高温度があるこ とがわかった。 その結果, 試料内部, たとえば今の条件 では $6 \mu \mathrm{m}$ の深さに図 2 のような高蒸気圧をもつ気泡が 発生する.この気泡をつつ薄層 (厚さ $\left.D_{b}\right)$ で注, 電子 の侵入モデルからわかるようにエネルギ損失が非常に少 


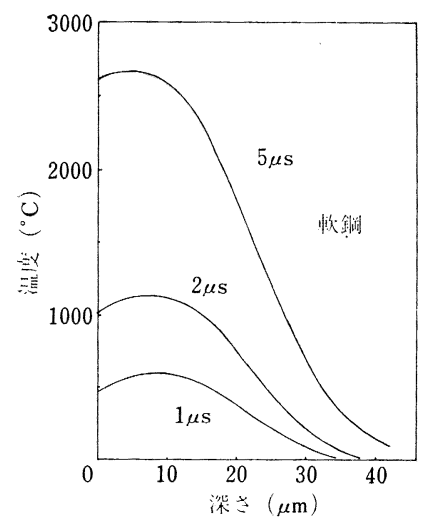

試料: 軟鋼 (S $15 \mathrm{C})$, ビ 一ム: $150 \mathrm{kV}, 40 \mathrm{~mA}$, ビーム径 $0.05 \mathrm{~cm}$

図 1

深さと温度上昇の関係

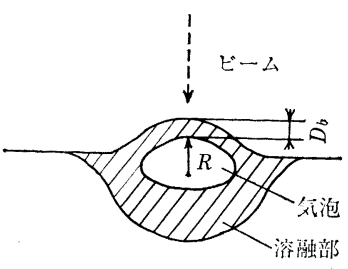

図 2 溶融部除去モデル

ないから の溶融部分まで到達する。その結果，気泡はさらに加熱 される. 表 1 に各試料について求めた最高温度発生深さ （気泡発生深さ $D_{b}$ ) を示す.

\section{2 除去作用の臨界条件}

金属の穴あけ加工中に, 溶融体の飛散を観察できる. この溶融体飛散の発生条件は, 図 2 から求めることがで きる. すなわち, 気泡内の蒸気圧 $p_{b}$ と溶融体の表面張 力 $\sigma$ による収縮圧 $p_{s}=2 \sigma / R$ ( $R$ 江気泡の曲率半径) の関 係が $p_{b}>p_{s}$ になったときに溶融体飛散が起こると考え る. 気泡半径がビーム半径 $R_{i}$ と等しいと仮定し（これ は，後述の図 4 より，加工初期の穴径がビーム径にほぼ 等しいことがわかるから妥当な仮定である)，また， $p_{b} \fallingdotseq$ $p_{s}$ とおくことによって求めた気泡温度 (溶融体飛散温 度) $T_{b}$ の例を表 1 に示す.

次に, $p_{b} \doteqdot p_{s}$ になるまでの時間 $\tau$ を求める. 図 1 の計 算には相变化を含めていないから, 相変化に必要なエネ ルギを考慮するため，いわゆる修正温度8)考考え，これ まで到達するのに必要な時間它求める.

蒸発には気泡内の蒸発(質量 $\left.m_{1}\right)$ と表面からの蒸発(質 量 $m_{2}$ ) がある. 気泡を球状（径をビーム径 $2 R_{i}$ と等しい とする) と仮定すれば，その体積 $V_{b}$ は $V_{b}=\frac{4}{3} \pi R_{i}{ }^{3}$ であ るから, 表 1 の圧力 $p_{b}$ と温度 $T_{b}$ を用いて質量 $m_{1}$ は式 (4) で計算できる.

$$
m_{1}=M \cdot \frac{p_{b} \cdot V_{b}}{G \cdot T_{b}}
$$

表 1 熱伝導計算から求めた臨界除去条件

\begin{tabular}{l|c|c|c|c}
\hline & 軟 & 鋼 & $\begin{array}{l}\text { アルミ } \\
\text { ウム }\end{array}$ & 銅 \\
\hline 気泡発生深さ $D_{b}(\mu \mathrm{m})$ & 6 & 25 & 2 \\
気泡压力 $p_{b}\left(\mathrm{dyn} / \mathrm{cm}^{2}\right)$ & $1.8 \times 10^{5}$ & $8.7 \times 10^{4}$ & $1.0 \times 10^{5}$ \\
気泡温度 $T_{b}\left({ }^{\circ} \mathrm{C}\right)$ & 2500 & 2000 & 2200 \\
融解熱の修正温度 $T_{0}\left({ }^{\circ} \mathrm{C}\right)$ & 590 & 450 & 550 \\
$T_{b}+T_{0}$ まで加熱するのに & 6 & 10 & 4 \\
必要な時間 $\tau(\mu \mathrm{S})$ & & & \\
\hline
\end{tabular}

表 2 除去における蒸発質量, 溶融質量および それに必要なエネルギ

\begin{tabular}{|c|c|c|c|c|}
\hline & & 軟 鋼 & $\begin{array}{l}\text { アルミ二 } \\
\text { ウム }\end{array}$ & 銅 \\
\hline 蒸発質量 (g) & $\begin{array}{c}m_{1} \\
m_{2} \\
m_{1}+m_{2}\end{array}$ & $\begin{array}{l}2.8 \times 10^{-9} \\
6.4 \times 10^{-8} \\
6.7 \times 10^{-8}\end{array}$ & $\begin{array}{l}8.0 \times 10^{-10} \\
2.5 \times 10^{-8} \\
2.6 \times 10^{-8}\end{array}$ & $\mid \begin{array}{l}2.0 \times 10^{-9} \\
5.4 \times 10^{-8} \\
5.6 \times 10^{-8}\end{array}$ \\
\hline 溶融質量 ( $\mathrm{g}$ ) & $m_{3}$ & $1.7 \times 10^{-5}$ & $2.6 \times 10^{-5}$ & $1.4 \times 10^{-5}$ \\
\hline $\begin{array}{l}\text { 蒸発に必要なエ } \\
\text { (cal) } \\
\text { 溶融に必要な工 }\end{array}$ & $E_{v}$ & $8.6 \times 10^{-5}$ & $8.4 \times 10^{-5}$ & $7.8 \times 10^{-5}$ \\
\hline ネルギ (cal) & $E_{m}$ & $8.8 \times 10^{-3}$ & $1.4 \times 10^{-2}$ & $3.5 \times 10^{-3}$ \\
\hline
\end{tabular}

ただし， $G$ : 気体定数， $T_{b}$ ：絶対温度に変換である. そ の計算結果を表 2 に示す。 また, 表面から蒸発する質量 $m_{2}$ は式(5)で計算できる9'.

$$
m_{2}=5.833 \times 10^{-2} p \sqrt{\frac{\bar{M}}{T}} \cdot S \cdot \Delta t
$$

ただし， $p$ : 表面の蒸気圧, $T$ : 表面の温度, $S$ : 蒸発面 積, $\Delta t$ : 蒸発時間である. 式(5)の $T$ は, 深さ $D_{b}$ にお ける温度が表 1 の $T_{b}$ になったときの表面温度と考えて, 式 (3) から, p 注温度 $T$ における蒸気圧として蒸気压曲 線10)より求める. $S$ を半球表面積 $\left(2 \pi\left(R_{i}+D_{b}\right)^{2}\right), \tau$ を $10 \mu \mathrm{s}$ としたときの質量 $m_{2}$ の計算結果を, また表 2 に 示す.

溶融体の質量 $m_{3}$ は, 計算上からは求まらないが, 溶 融が図 2 の薄層のみと仮定すれば，式 (6) で計算できる.

$$
m_{3}=\frac{2}{3} \pi\left\{\left(R_{i}+D_{b}\right)^{3}-R_{i}^{3}\right\}
$$

その計算結果もまた表 2 に示す.

これらの計算より, 質量 $m_{1}, m_{2}$ の蒸発に必要なエネ ルギ $\left(E_{v}\right)$ および質量 $m_{3}$ の溶融に必要なエネルギ $\left(E_{m}\right)$ は表 2 のようになり，図2のモデルからは，

$$
m_{1}+m_{2} \ll m_{3} \text { および } E_{v} \ll E_{m}
$$

が成立つ、これから，相変化のエネルギとしては，溶融 エネルギのみを考えればよいことがわかる。それゆえ， 溶融体除去が起こる時間は, 融解熱 $L_{m}$ の夕を考慮し, これを $T_{0}=L_{m} / c$ ( $c$ は比熱) なる関係で温度 $T_{0}$ に変換 して気泡温度 $T_{b}$ に含め, 温度 $\left(T_{b}+T_{0}\right)$ まで上昇させる 
のに必要な時間として求めることができる。式(3)を用 いて求めた時間 $\tau$ を表 1 に示す.

ただし，この時間は第 1 回目の溶融体除去が起こるま での時間であり, 第 2 回目以後は, 新しい表面（深さ方 向に $D_{b}$ の位置) 付近がすでに加熱された状態にあるか ら，除去に要する時間は表 1 の值よりも小さくなる。す なわち, 溶融体飛散の間隔は, さらに短くなる.

\section{3. 実験および検討}

\section{1 実験方法}

実験は，ビームをパルス化し，金属試料に各種パルス 幅ビームを1回だけ照射して行った。ビーム条件および 試料材質は次のとおりである.

$$
\begin{aligned}
& \text { ビーム加速電圧： } 150 \mathrm{kV} \\
& \text { ビーム電流 : } 40 \mathrm{~mA} \\
& \text { ビーム径(平均)：0.05 cm（パワー密度： } 3 \times 10^{6} \mathrm{~W} \text { / } \\
& \mathrm{cm}^{2} \text { ) }
\end{aligned}
$$

パルス幅 $\quad: 50,100,200,500 \mu \mathrm{s}, 1,2,5,10 \mathrm{~ms}$ 試料材質： 軟鋼 (S15 C), アルミニウム, 銅 ビーム径は，アルミニウム管 $(20 \mu \mathrm{m})$ を上記パルス幅 で加工した結果，一定穴径を得たので，その穴径によっ て定めた。また，ビーム形状は，だ円であるため，試料 表面における加工穴形状もだ円（試料：軟鋼，パルス幅： $1 \mathrm{~ms}$ で長径/短径门1.3) となる，それゆ光，穴径は平均 值を求めた. 次に断面を観察するため, 試料を切断し, エッチングした.

\section{2 実験結 果}

\section{2 .1 試料表面における加工穴径の変化}

加工穴の断面形状は，完全な円筒形にならず，特に穴 の先端に現れる溶融層では先が細くなっている.すなわ ち, 図 3 の断面例 (軟鋼, パルス幅 $5 \mathrm{~ms}$ ) に示すよう に，除去加工された部分は円すい台に近い形を，その先 端の溶融層では円すい形に近い形をしている，そこで， ここでは最大径をとる試料表面の穴径で加工穴径を代表 させた，パルス幅と穴径の関係を図 4 に示す．軟鋼，銅 の場合, 穴径はパルス幅が $1 \mathrm{~ms}$ 以上になると急激に増 大する、アルミニウムの場合は，さらに短いパルス幅で 増大する. 図 4 の中にアルミニウム, 銅についてのパル ス幅 $5,10 \mathrm{~ms}$ のデータの記入がないのは，溶融体による 穴ふさがりが顕著となって，穴あけではなくなり，溶接 加工の領域に入ったためである.

このようなあるパルス幅を境界とした穴径の増大は， ビームエネルギの吸収位置が常に穴先端にあるのではな く, 試料材質によって定まる照射時間以上になると表面 近くに移動すること, すなわ穴あけの進行形態が照射

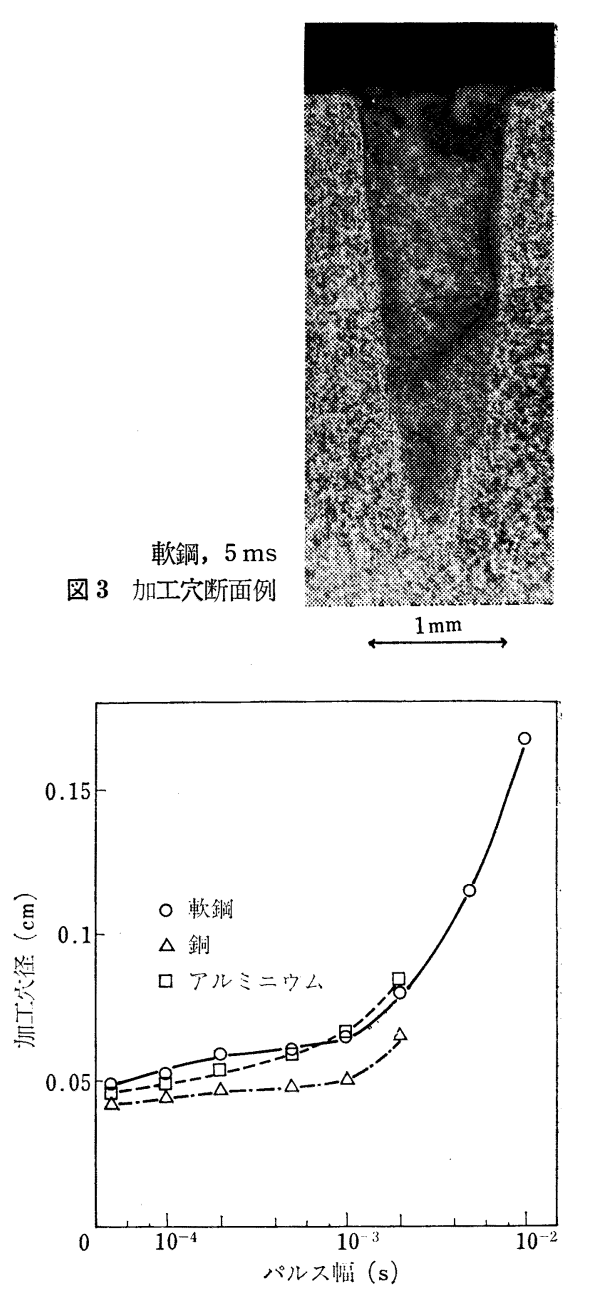

図 4 パルス幅と加工穴径の関係

時間によって変化することを示唆している。

次に, 試料表面における溶融部径の広がりを考える. この溶融部径は，以下の理由により相対的な值で求め た。すなわち，3.1項で述べたように，穴形状はだ円形 になっているが，各パルス幅について同一方向に切断す れば，パルス幅に対する溶融部径の変化は十分に表すこ とができる．パルス幅 $50 \mu$ 危基準としたときのアルミ ニウムの溶融部变化を図 5 に示す. 溶融部径も穴径と同 じ傾向, すなわちパルス幅 $200 \mu \mathrm{s}$ 程度を境界として増 大する傾向を示す. これは, 図 4 で述べた穴あけ進行形 態の変化をさらに裏づけるものである.

3.2 .2 加工穴深さおよび溶融深さの変化

パルス幅が短い範囲では, 加工穴先端の溶融層は薄 い. しかし，パルス幅が長くなるに従って厚くなる. 軟 鋼，アルミニウム，銅についての穴深さ $D_{h}$ を図 6 に, 


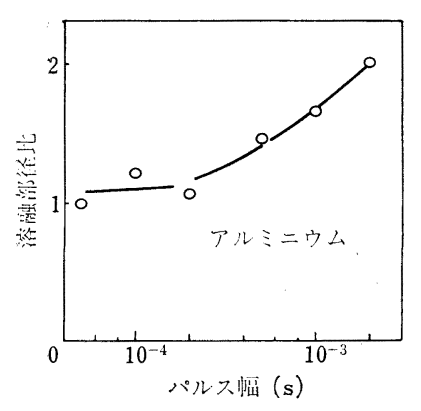

図 5 パルス幅と溶融部径比の関係

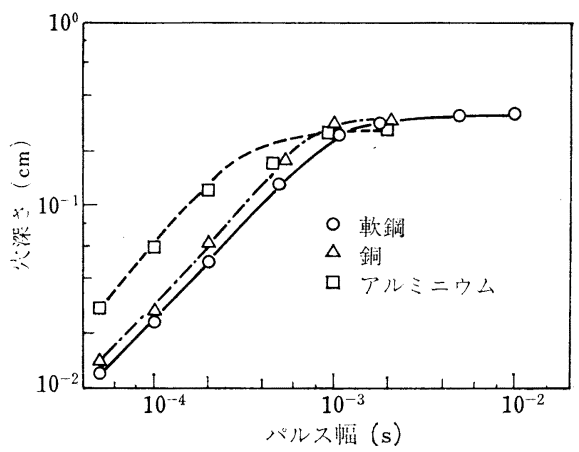

图 6 パルス幅と穴深さの関係

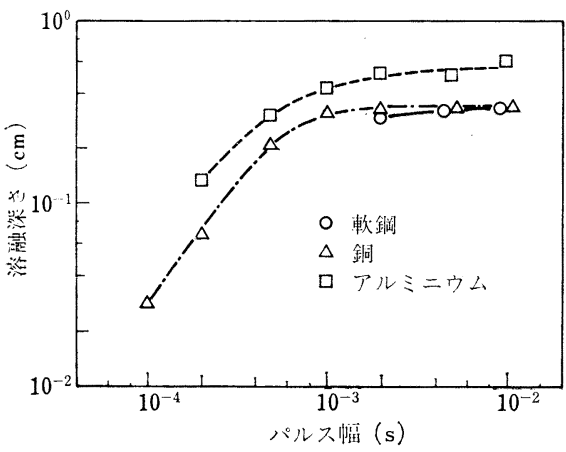

図 7 パルス幅と溶融深さの関係

溶融深さ (表面ふら溶融部先端までの長さ) $D_{m}$ を図 7 に 示す，パルス幅が短い範囲では， $D_{h}, D_{m}$ の值にほとえ ど差がないため図示せず，溶融層厚み $\Delta D\left(=D_{m}-D_{h}\right)$ が $\Delta D / D_{h} \geq 0.1$ の範囲についてのみ示した。

困6より明らかなように, 初めは, 穴深さはパルス幅 に比例して嬶加するが，試料材質によって定まるパルス 幅以上になると, 穴深さの増加率は急激に減少し, 穴深 さは飽和する，同時に，溶融深さ，すなわち溶融層厚み が増加する。この現象が発生するパルス幅は, 加工穴径 に急激な增大を生ずるパルス幅にほぼ一致している。
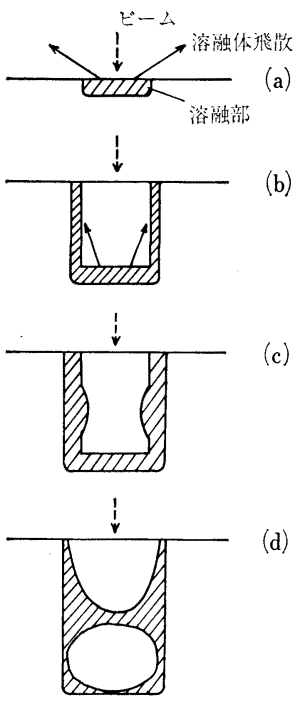

図 8 溶融体の動きと穴あけ機構

\section{3 検 討}

\section{3 .1 穴深さの飽和に関する解析}

実験中に溶融体の飛散を肉眼で観察できた，溶融体飛 散は，パルス幅が短い間は試料表面近くに多く，パルス 幅が長くなると試料表面に垂直方向に多くなる．この傾 向, 図 3 の穴ふさがり，図 4 の加工穴径の急激な増大お よび図 6 の穴深さの飽和現象を考慮して，金属の穴あけ 機構を図 8 のように考える。すなるち，パルス幅が短い 間は溶融体飛散に対して障害物がないため(図 8 (a)), 図2で示した除去機構によりそのまま飛散して穴あけが 進行する，しかし，穴が深くなると（図8(b))，溶融体を 穴の外へ除去できない確率が大きくなり, 図 8(c)のよ うに側面に付着する。この溶融体は，側面に付着したま ま静止しているのではなく, 表面張力によって収縮運動 を起こし，図8(d) のように穴の途中をふさぐ.すると， ビーム泬先端ではなく，ふさがった所で吸收され，そ の結果，その部分の穴径の増大を生ずる。また，吸収位 置においても, 図 2 の機構により除去が起こり, かつビ 一ムを吸収した溶融体のうち穴先端に近い部分は，除去 の際の蒸気圧によって穴先端あるいは先端近くの穴側面 へ移動し，溶融層の厚みも大きくなる，すなわち，穴の ふさがりが起こる前後においてビームの吸収位置は変化 する・

穴がふさがる時間を，溶融体の収縮運動のみを考えて 求める. 溶融体部分を中空円柱形（内径 $2 R_{\text {in }}$ ) とし, 収 縮開始より内径が $2 R$ になったときの単位長さ当たりの エネルギを考えると次のようになる。

表面張力による仕事 $W_{s}=2 \sigma\left(R_{i n}-R\right)$ 
溶融体の運動エネルギ $W_{m}=\frac{1}{2} \rho \int_{R}^{R_{o}} 2 \pi r\left(\frac{\mathrm{d} r}{\mathrm{~d} t}\right)^{2} \mathrm{~d} r$

$$
=\pi \rho\left(\frac{\mathrm{d} R}{\mathrm{~d} t}\right)^{2} R^{2} \log \frac{R_{0}}{R} *
$$

ただし, $R_{o}$ : 円柱外半径 (一定とする), $\mathrm{d} R / \mathrm{d} t$ ：内半径 $R$ における収縮速度である。それゆえ，

$$
W_{s}=W_{m}
$$

とおくことにより, 内半径の収縮速度 $\mathrm{d} R / \mathrm{d} t$ が求まる. したがって，図 8(d)のように完全に穴がふさがるのに必 要な時間 $t_{c}$ は, 式 (8)で与えられる.

$$
t_{c}=\left(\frac{\rho}{2 \sigma}\right)^{1 / 2} \int_{0}^{R_{i n}} \sqrt{\frac{R^{2}}{R_{i n}-R} \log \frac{R_{o}}{R}} \mathrm{~d} R
$$

たとえば， $R_{i n}=R_{i}$ (ビーム半径) とし, さらに， $R_{o}=$ $3 / 2 R_{i}$ と仮定すれば, 軟鋼, アルミニウム, 銅について $t_{c}$ の值は，それぞれ $190 ， 160 ， 240 \mu \mathrm{s}$ となる. この值 は，図6,7からわかる溶融層厚みの増加にほぼ対応して いる.すなわち，ビーム照射がこの程度のパルス幅より 短ければ，溶融体除去は穴先端で起こるが，さらに長く なると，ビームは穴先端までは到達しにくくなる．

次に，穴がふさがった後の加工エネルギのバランスを 考える. 穴の周囲の温度分布が定常状態にあるとすれ ば，図 8 のモデルについては，ビームエネルギは穴先端 の部分を除去するのに必要なエネルギと穴ふさがりの部 分で吸収されるエネルギの和となる ${ }^{11)}$. 穴先端の除去に 必要なエネルギは, 表 2 の值より溶融除去のみを考光れ ばよい，また，時間 $\mathrm{d} t$ における穴のふさがりは，穴深 さ $D$ と $\mathrm{d} t$ の積 $D \mathrm{~d} t$ に比例して起こると考えられる. そ れゆえ，穴ふさがりの部分の溶融体が穴先端にもどるこ とを無視して近似的に考えると, エネルギバランスは式 (9)となる.

$$
Q \mathrm{~d} t=\pi R_{r}^{2} \rho\left(L_{m}+c T_{b}\right) \mathrm{d} D+\alpha D \mathrm{~d} t
$$

ただし， $Q$ : ビームパワー, $R_{r}$ : 穴先端の除去部の半径, $\alpha$ ：試料材質によって定まる定数である。 また， 2.2 項 の解析および図 3 より $R_{r} \fallingdotseq R_{i}$ (ビーム半径) とおけ, 電 子ビーム機のレンズは遠焦点であることを考えれば，図 6 に示す深さまでは， $R_{i}$ は一定とおける ${ }^{12)}$. さらに, $\alpha$ が次の条件を满たせば，式 (9) は穴がふさがらない状態 $\left(t \leqq t_{c}\right)$ も表しうる.

$$
t \leqq t_{c}: \alpha=0 \text { および } t>t_{c}: \alpha>0
$$

式 (9) を式 (10), $t=0$ で $D=0$ および $t=t_{c}$ で $D$ は連続

\begin{tabular}{|c|c|c|c|}
\hline & 軟 鋼 & |アルミニウム & 銅 \\
\hline$\alpha(\mathrm{cal} / \mathrm{cm} \cdot \mathrm{s})$ & $6.3 \times 10^{3}$ & $9.5 \times 10^{3}$ & $1.3 \times 10^{4}$ \\
\hline $\begin{array}{l}\text { 誝差 (\%) } \\
\text { (パルス幅) }\end{array}$ & $\begin{array}{c}14 \\
(1 \mathrm{~ms})\end{array}$ & $\begin{array}{c}21 \\
(200 \mu \mathrm{s})\end{array}$ & $\begin{array}{c}25 \\
(500 \mu \mathrm{s})\end{array}$ \\
\hline
\end{tabular}
であることを考慮して解くと次式を得る。

* 条件： $r \frac{\mathrm{d} r}{\mathrm{~d} t}=R \frac{\mathrm{d} R}{\mathrm{~d} t}$ を用いる.
表 $3 \alpha$ の值および穴深さの実験值と 計算値の間の最大䛊差

$$
\left.\begin{array}{rl}
t \leqq t_{c}: \quad D= & \frac{Q}{\pi R_{i}^{2} \rho\left(L_{m}+c T_{b}\right)} t \\
t>t_{c}: D= & \frac{Q}{\alpha}\left\{1-\exp \left(-\frac{\alpha\left(t-t_{c}\right)}{\pi R_{i}^{2} \rho\left(L_{m}+c T_{b}\right)}\right)\right\} \\
& +\frac{Q}{\pi R_{i}^{2} \rho\left(L_{m}+c T_{b}\right)} t_{c}
\end{array}\right\}
$$

式 (11) で $t \rightarrow \infty$ とすると $D$ は一定となるから，パルス 幅が長くなると穴深さが飽和することを説明できる。 た， $t_{c}$ の值として式 (8)より求めた值に最も近い実験值 $(200 \mu \mathrm{s})$ を用い, 式 (11) の 飽和深さの 理論值 $Q / \alpha+Q /$ $\pi R_{i}^{2} \rho\left(L_{m}+c T_{b}\right) \cdot t_{c}$ と図 6 の飽和深さの実験值から $\alpha$ を 求めた結果が表 3 である。これから，熱伝導率の大きな 試料ほど大きな值をとることがわかる。すなわち，熱伝 導率の大きな試料は，穴側面からの熱伝導損失が大きい ため側面の温度低下がはやく，したがって蒸気圧の低下 も急速であり，穴ふさがりが頻繁に起こるととを示す. また，穴径の増大が銅よりもアルミニウムの場合にはや く起こるのは，銅の方が熱伝導率が大きく，融点が高 く, かつ単位体積当たりの融解熱が大きいため, 溶融さ れる領域が狭くなるためと思わ机る。

次に，穴深さの理論值 $D_{c a}$ を式 (11) と表 $3 の \alpha$ から求 めて, 図 6 の穴深さの実験值 $D_{e x}$ との相対誤差 $\left(D_{e x}-\right.$ $\left.D_{c a}\right) / D_{e x}$ を計算した。結果を表 3 に示す. 最大值は, 銅の $t=500 \mu \mathrm{s}$ に打ける $25 \%$ である。乙れは，式(9)に 含まれない熱伝導項によるためと考えられ，穴深さをさ らに厳密に表すためには，熱伝導項も考慮すべきことを 示唆している.

\section{3 .2 穴あけ速度に閔する解析}

穴深さがパルス幅に比例する範囲の穴あけ速度を考え る。このパルス偪では，穴はふさがっていないと考えら れるから, 式(11)より, 穴あけ速度として次式觉得る。

$$
\frac{\mathrm{d} D}{\mathrm{~d} t}=\frac{Q}{\pi R_{i}^{2} \rho\left(L_{m}+c T_{b}\right)}
$$

一方, 2.2 項の解析の速度は次式となる.

$$
\frac{\mathrm{d} D}{\mathrm{~d} t}=\frac{D_{b}}{\tau}
$$

式 (12)，(13) から求めた值と実験值を表 4 に示す. 式 (12) から求めた值は，実験值とほぼ一致するが，式(13)から 
表 4 初期穴あけ速度 $(\mathrm{cm} / \mathrm{s})$

\begin{tabular}{|c|c|c|c|}
\hline & 軟 鋼 & アルミニウム & 銅 \\
\hline 実験值 & $2.4 \times 10^{2}$ & $5.4 \times 10^{2}$ & $2.6 \times 10^{2}$ \\
\hline 計算値 $D_{b} / \tau$ & $1.0 \times 10^{2}$ & $2.5 \times 10^{2}$ & $0.5 \times 10^{2}$ \\
\hline $\begin{array}{l}\text { 計算值 } \\
\frac{Q}{\pi R_{i}^{2} \rho\left(L_{m}+c T_{b}\right)}\end{array}$ & $2.8 \times 10^{2}$ & $5.4 \times 10^{2}$ & $3.3 \times 10^{2}$ \\
\hline
\end{tabular}

求めた值は，少し低めとなる。この理由は，次のように 考えられる. 式 (13) の值は, 試料を常温から加熱した場 合の溶融体除去発生の時間安基準としているが，第 2 回 目以後の除去注 2.2 項で考えたように，予熱の状態から の除去過程であるため， $\tau$ の值は表 1 の值より，小さく なる. その結果, $D_{b} / \tau$ は表 4 の值より大きくなり, 実 験值に近づく.

本節の解析は, 気泡の発生に基づいた溶融体除去によ って穴あけが進行するという2.2 項の解析を, さらに裏 づけるものである。

\section{4. 結 論}

高パワー密度電子ビームによる金属の穴あけ加工の実 検および解析を行い, 次の結論を得た。

（1）電子の試料中への侵入を考慮した熱伝導計算よ り，試料内部に最高温度があることがわかった。

（2）気泡の発生に基づいた溶融体除去による穴あけの モデルを考えた。

（3）（2）のモ゙ルによる穴あけ速度は, 実験值とほぼ一 致した。

(4) 溶融体の穴内部における動きから穴のぶさがりを 考え，ビームエネルギのバランスを計算した。 この 結果から，穴深さの飽和を説明した．さらに，この 計算による穴あけ速度も実験值とほぼ一致した。
終わりに，本研究を行うにあたってご指導いただいた 東京理科大学・谷口紀男先生, ならびに本実験にご協力 いただいた日本電気(株) ・長谷隆裕氏, 東京電機大学学 生・竹村純一君に深く感謝致します。

\section{参 考 文 献}

1) O.C. Wells: Electron Beams in Micro-electronics, Proc. 3rd Symp. Electron Beam Technology, Alloyd Electronics Corp. (1961) 291.

2) R. Bakish: Introduction to Electron Beam Technology, John Wiley \& Sons, N. Y. (1962) 336.

3) G. Pahlitzsch and A. Visser: Materials Removal Processes in Laser and Electron Beam Machining, 3rd Int. Conf. Electron and Ion Beam Science and Technology, The Electrochemical Soc. (1968) 335.

4）宮崎俊行，谷口紀男：高動力密度電子ビームの金属への 侵入, 精密機械, 38, 11 (1972) 960.

5) R. Shimizu, T. Ikuta and K. Murata: The Monte Carlo Technique as Applied to the Fundamentals of EPMA and SEM, J. Appl. Phys., 43, 10 (1972) 4233.

6) K. Kanaya and S. Okayama: Penetration and Energy-loss Theory of Electrons in Solid Targets, J. Phys. D, Appl. Phys., 5, 1 (1972) 43.

7) H. S. Carslaw and J. C. Jaeger: Conduction of Heat in Solids, 2nd ed., Oxford (1965) 264.

8）宮崎俊行, 谷口紀男：電子ビーム加工・レーザ加工にお ける温度解析，精密機械， 36, 1 (1970) 21.

9）たとえば，沢木 司：真空蒸着，日刊工業新聞社(1965) 2.

10) R.E. Honig: Vapor Pressure Data for the Solid and Liquid Elements, RCA Rev., 23, Dec. (1962) 567.

11) H. G. Landau: Heat Conduction in a Melting Solid, Quart. Appl. Math., 8, 1 (1950) 81.

12）荒田吉明, 富江通雄, 寺井 清, 永井義夫, 服部哲二： 高エネルギ密度ビーム形状の決定について (その 1), 電 子ビーム溶接研究委員会資料 EBW-69-72 (1972). 